\title{
A new record of Craspedacusta sowerbii, Lankester 1880 (Cnidaria, Limnomedusae) in Northern Italy
}

\author{
Fabrizio STEFANI*, Barbara LEONI ${ }^{1)}$, Alessandro MARIENII ${ }^{2)}$ and Letizia GARIBALDI ${ }^{1)}$ \\ Dept. of Biotechnology and Biosciences, University of Milano-Bicocca, p.za della Scienza 2, 20126 Milan, Italy \\ ${ }^{1)}$ Dept. of Environmental Sciences, University of Milano-Bicocca, p.za della Scienza 1, 20126 Milan, Italy \\ ${ }^{2)}$ Centro Studi Biologia ed Ambiente, snc., Erba, Italy \\ *email corresponding author: fabrizio.stefani@unimib.it
}

ABSTRACT

A new record of the freshwater jellyfish Craspedacusta sowerbii in Northern Italy is reported. The medusae bloom occurred in a small oligo-mesotrophic artificial lake during July, 2009. At the time of sampling, the medusae were all immature, reached low density and showed feeding preference towards the Daphnia complex of species, the most abundant zooplanktonic species in the lake. Negative feeding selectivity towards small Rotifera was demonstrated. The occasional occurrence of a $\mathrm{C}$. sowerbii bloom in this lake suggests the distribution range of this species may be largely underestimated, and its potential impact on the zooplankton community remains unknown.

Key words: freshwater jellyfish, exotic species

\section{INTRODUCTION}

Among the numerous exotic species invading European freshwater ecosystems, the jellyfish Craspedacusta sowerbii is probably one of the most elusive and unknown taxa. Within the genus Craspedacusta, 11 species were originally described (Jankowski 2001), native of the Yangtze River area in China (Kramp 1961), which were synonymised into the two species Craspedacusta sowerbii and Craspedacusta sinensis, following morphological (Jankowski 2001) and molecular phylogenetic analysis (Fritz et al. 2009; Zhang et al. 2009). Among the two species, only $C$. sowerbii has been recognized as a cosmopolitan invader (Rayner 1988; Dumont 1994), probably due to specific adaptations favouring dispersal such as the capacity to develop a durable, chitin covered, resting body (Acker $\&$ Muscat 1976; Bouillon \& Boero 2000), several forms of vegetative reproduction (Reisinger 1957), and longterm survival without sexual reproduction (Fritz et al. 2007).

Despite records from many regions of the world (Acker 1976; Rayner 1988; Devries 1992; Dumont, 1994) verifying the dispersal of this species, few published data or information are available regarding the detailed distribution within each country or the dispersal routes and patterns. Indeed, the species is often present as a small polyp, which remains undetected for years before a medusae bloom occurs. A detailed review of all the national records is available only for Germany (Fritz et al. 2007). Within drainages of the Italian peninsula, a few records have been published (Stefanelli 1948; Ramazzotti 1962; Marchetti et al. 1968; Badino \& Lodi 1972; Cotta Ramusino 1972), demonstrating the high adaptability of this species from Northern to Central regions and insular natural and artificial basins. However, evaluation of the trophic impact of this species and its preferential ecological niche is still missing for the Italian context. In contrast, information on this species is available for a Spanish reservoir (Pérez-Bote et al. 2006) and a German pond (Spadinger \& Maier 1999). In both cases, a positive selectivity towards prey species such as cyclopoid copepods and cladoceran Daphnia sp. was demonstrated, probably explained by selection based on prey size. Contrasting preferences have been detected for Rotifera. On the contrary, a significant predator impact was excluded at least for the German study case, even if the authors did not exclude the possibility of a zooplankton composition shift towards smaller taxa. Nevertheless, studies on controlled mesocosms or enclosures (Jankowski 2004; Jankowski et al. 2005; Smith \& Alexander 2008) or in nature in New Zealand (Boothroyd et al. 2002,) have revealed a significant effect of $C$. sowerbii on zooplankton communities, with potential trophic cascade effects.

In this work, a new record of $C$. sowerbii from an artificial lake in Northern Italy is reported. Moreover, the physical, chemical and trophic characterization of this ecosystem and an evaluation of predation selectivity on the zooplankton community have been conducted.

\section{STUDY AREA AND METHODS}

During July of 2009, a medusae bloom occurred in a small artificial lake (Lake Malpaga, 9 ${ }^{\circ} 13^{\prime} 56^{\prime \prime} \mathrm{E}, 45^{\circ} 46^{\prime}$ $20 " \mathrm{~N}$ ) in the Como Province. The lake is located at 330 $\mathrm{m}$ a.s.l. and has a maximum length of $290 \mathrm{~m}$, a maximum width of $160 \mathrm{~m}$, and a maximum depth of about 10 $\mathrm{m}$. Tributaries are absent, and the water supply depends primarily on rain and underground springs.

Chemical data classify the lake between an oligotrophic and a mesotrophic status, with a total P concentration of $12 \mu \mathrm{g} \mathrm{L} \mathrm{L}^{-1}$ and a Secchi disk depth in summer of about $4 \mathrm{~m}$. The fish assemblage is dominated by cypri- 
nids, with Scardinius erythrophthalmus representing the major fish species in the lake, although the allochtonous centrarchids Lepomis gibbosus and Micropterus salmoides are common, together with the percid Perca fluviatilis. Larvae of Chaoborus flavicans (Meigen) are found in the lake. This species is widely distributed in the Holarctic Region, has four larval instars, and is usually univoltine. It inhabits shallow lakes and is adapted to coexist with dense fish populations, which is usually explained by its ability to avoid predation by vertical migrations (McQueen et al. 1999; Gliwicz et al. 2006). A recent qualitative analysis of the zooplankton community (summer 2009, unpublished data) showed a species composition typical of a mesotrophic shallow environment, quite similar to those commonly found in shallow water bodies in the subalpine Italian lake district (e.g., Lake Segrino, Lake Alserio and Lake Montorfano; Leoni et al. 2007).

In the zooplankton assemblage we found nine taxa of Rotifera, three taxa of Cladocera, and three taxa belonging to the Copepoda. Calanoids were entirely represented by the species Eudiaptomus padanus padanus, while cyclopoids were represented by Mesocyclops leuckartii and Thermocyclops dybowski. During the summer, Cladocera were dominated by the Daphnia galeata $\times$ hyalina $\times$ cucullata complex, and Rotifera by the genus Polyarthra.

The phytoplanktonic community is dominated by Dinophyceae, with Gymnodinium lacustre as the most abundant species, followed by Peridinium aciculiferum (also observed as cysts), Gymnodinium ordinatum and Ceratium hirundinella. Cyclotella comensis and $C$. radiosa are the most frequent among the Bacillariophyceae, while Navicula radiosa and Diploneis elliptica are present but rare. Cyanobacteria are also rare, being represented only by the two colonial and globular species Chroococcus limneticus and Aphanocapsa pulchra. Chlorophyceae are represented by several but rare species, such as Chlamydomonas globosa, Carteria sp., Elakatothrix viridis, two Closterium species, Coelastrum microporum, Oocystis solitaria, O. lacustris and Characium sp.

Similarly, the Chrysophyceae Mallomonas elongata, M. acaroides, Chromulina parvula and Dinobryon divergens are rare, but subject to short demographic peaks. Finally, among the Chryptophyceae, Rhodomonas minuta, Cryptomonas erosa and C. tetrapyreinodosa have been identified.

A visual inspection of the jellyfish distribution was undertaken in all of the lake, and a total of 30 specimens were collected using a plankton net or directly with a plastic beaker and then fixed in a $30 \%$ ethanol solution for conservation. The sex was determined by observing the gonads with the use of a microscope at $40 \times$ and $100 \times$ magnification, as indicated in Pérez-Bote et al. (2006). The umbrella diameter was estimated along two perpendicular axes using a graduated reference, while the gut content was examined after washing out the external zooplankton. The stomachs were dissected and preys were identified and counted.

At the time of the jellyfish collection, the zooplankton of the lake was sampled either along all of the water column from a $10 \mathrm{~m}$ depth to the surface, or along a 20 $\mathrm{m}$ horizontal path at a $2 \mathrm{~m}$ depth, which was the depth preferred by most of the jellyfish at the time of sampling (6-8 p.m.); $200 \mu \mathrm{m}$ and $50 \mu \mathrm{m}$ plankton nets $40 \mathrm{~cm}$ in diameter were used. The use of this type of net and mesh sizes efficiently captures zooplankton like Rotifera, Cladocera and Copepoda, including copepodites and nauplii, and occasionally plankton organisms such as dipteran larvae. The zooplankton was preserved in a $4 \%$ buffered sucrose-formalin solution. In the laboratory, identification and counts of adult crustaceans and rotifers were made mostly to the species level using an optical microscope. Three counts for each sampling approach were performed. Measurement of total length of prey was performed using a PC provided with image analysis software. Pictures of prey were taken using a digital camera (Olympus Camedia C-7070) installed on a microscope (Wild Leitz GMBH).

Food selectivity was calculated by applying the prey selection index (V) proposed by Pearre (1982). The significance of positive or negative selection was tested by calculating the $\chi^{2}$ statistic as proposed by the same author.

Three samples of water were collected using a Van Dorn bottle at the surface, and at $4 \mathrm{~m}$ and $8 \mathrm{~m}$ depths for the determination of the principal chemical parameters as represented by the principal compounds of nitrogen and phosphorous, and the principal ions and silicates. A vertical profile of temperature, oxygen concentration and saturation, $\mathrm{pH}$ and conductivity from the surface to the bottom was also constructed using a multiparameter meter.

\section{RESULTS AND DISCUSSION}

During the jellyfish bloom, the lake was stratified, showing a thermocline between a depth of 5 and $6 \mathrm{~m}$, with a high superficial temperature (Tab. 1) and deeper values consistent with the optimal growth temperature of $19-25{ }^{\circ} \mathrm{C}$ for this species (McClary 1959; Acker 1976). The oxygen concentration was elevated up to a depth of $7 \mathrm{~m}$, while the low temperature and oxygen content near the bottom likely reflected the extensive presence of water springs. The lake shows a low level of nitrogen and phosphorous loads, while levels of silicates and calcium showed an increase approaching the bottom, probably reflecting the significant input of underground water. Overall, the lake appears to have a mesooligotrophic status. Specimens of $C$. sowerbii were present at a density largely inferior to the values of 1 specimen $\mathrm{m}^{-2}$ or 1 specimen $\mathrm{m}^{-3}$ reported in the literature (Spadinger \& Maier 1999; Péreze-Bote et al. 2006), yet their distribution appeared slightly biased towards the shaded portion (NW) of the lake. Considering the complete absence of wind and the stable weather condi- 
Tab. 1. Physical and chemical parameters estimated at Lake Malpaga during the $C$. sowerbii bloom. Temperature, pH, oxygen concentration and conductivity were measured at 9 points along the vertical depth profile, while the determination of the most important chemical compounds and ions were estimated at the surface, $-4 \mathrm{~m}$ and $-8 \mathrm{~m}$.

\begin{tabular}{|c|c|c|c|c|c|c|c|c|c|c|c|c|c|c|c|c|c|c|c|c|c|}
\hline $\begin{array}{l}\text { Depth } \\
\text { m }\end{array}$ & $\underset{ }{\text { Temp. }}$ & $\mathrm{pH}$ & $\begin{array}{l}\mathrm{O}_{2} \\
\%\end{array}$ & $\begin{array}{c}\mathrm{O}_{2} \\
\mathrm{mg} \mathrm{L}^{-1}\end{array}$ & $\begin{array}{l}\text { Cond. } \\
\mu \mathrm{S} / \mathrm{cm}\end{array}$ & $\begin{array}{c}\text { Alc. } \\
\text { meq } L^{-1}\end{array}$ & $\begin{array}{c}\text { Ptot } \\
\mu \mathrm{g} \mathrm{L}^{-1}\end{array}$ & $\begin{array}{l}\text { P orto } \\
\mu \mathrm{g} \mathrm{L}^{-1}\end{array}$ & $\begin{array}{c}\text { Ntot } \\
\mu \mathrm{g} \mathrm{L}^{-1}\end{array}$ & $\begin{array}{l}\mathrm{N}-\mathrm{NO}_{3} \\
\mu \mathrm{g} \mathrm{L}^{-1}\end{array}$ & $\begin{array}{c}\mathrm{N}_{-\mathrm{NH}_{4}}^{+} \\
\mu \mathrm{g} \mathrm{L}^{-1}\end{array}$ & $\begin{array}{l}\text { N-inor } \\
\mu \mathrm{g} \mathrm{L}^{-1}\end{array}$ & $\begin{array}{l}\text { N-org } \\
\mu \mathrm{g} \mathrm{L}^{-1}\end{array}$ & $\begin{array}{c}\mathrm{SiO}_{2} \\
\mu \mathrm{g} \mathrm{L}^{-1}\end{array}$ & $\begin{array}{c}\mathrm{Cl}- \\
\mathrm{mg} \mathrm{L}^{-1}\end{array}$ & $\begin{array}{l}\mathrm{SO}_{4}{ }^{2-} \\
\mathrm{mg} \mathrm{L}^{-1}\end{array}$ & $\begin{array}{c}\mathrm{Ca}^{2+} \\
\mathrm{mg} \mathrm{L}^{-1}\end{array}$ & $\begin{array}{c}\mathrm{Mg}^{2+} \\
\mathrm{mg} \mathrm{L}^{-1}\end{array}$ & $\begin{array}{c}\mathrm{Na}^{+} \\
\mathrm{mg} \mathrm{L}^{-1}\end{array}$ & $\begin{array}{c}\mathrm{K}^{+} \\
\mathrm{mg} \mathrm{L}^{-1}\end{array}$ & $\begin{array}{c}\mathrm{Sr}^{2+} \\
\mathrm{mg} \mathrm{L}^{-1}\end{array}$ \\
\hline Surf. & 28.3 & 8.1 & 115 & 8.7 & 344 & 3.2 & 5 & 3 & 653 & 190 & 22 & 212 & 441 & 969 & 6.6 & 17.8 & 45.1 & 13.8 & 2.5 & 2.5 & 1.0 \\
\hline-1 & 27.2 & 8.0 & 122 & 9.3 & 343 & - & - & - & - & - & - & - & - & - & - & - & - & - & - & - & - \\
\hline-2 & 26.7 & 7.9 & 120 & 9.3 & 342 & - & - & - & - & - & - & - & - & - & - & - & - & - & - & - & - \\
\hline-3 & 26.4 & 7.7 & 123 & 9.6 & 341 & - & - & - & - & - & - & - & - & - & - & - & - & - & - & - & - \\
\hline-4 & 24.3 & 7.8 & 136 & 11.0 & 361 & 3.4 & 7 & 3 & 673 & 178 & 29 & 207 & 466 & 1062 & 6.7 & 18.3 & 48.1 & 14.1 & 2.6 & 2.6 & 1.0 \\
\hline-5 & 18.2 & 7.9 & 158 & 14.4 & 374 & - & - & - & - & - & - & - & - & - & - & - & - & - & - & - & - \\
\hline-6 & 13.9 & 7.8 & 130 & 12.9 & 361 & - & - & - & - & - & - & - & - & - & - & - & - & - & - & - & - \\
\hline-7 & 11.1 & 7.4 & 63 & 6.7 & 372 & - & - & - & - & - & - & - & - & - & - & - & - & - & - & - & - \\
\hline-8 & 10.1 & 7.2 & 27 & 2.9 & 377 & 3.9 & 24 & 9 & 800 & 20 & 33 & 53 & 747 & 2681 & 7.1 & 18.2 & 55.5 & 15.0 & 2.5 & 2.5 & 1.1 \\
\hline
\end{tabular}

Tab. 2. List of zooplankton taxa found in the Lake Malpaga and preyed by C. sowerbii. The density in the lake, the frequency of occurrence in the stomach and mean percentage of prey $(\%$ of individuals in a stomach) was reported, together with the estimates of selectivity index. Wherever any estimates is not reported, the taxon has been listed as present in the lake in previous sampling (unpublished data), but not detected during the present census. In brackets, standard deviations are reported. * significant at $p<0.05$.

\begin{tabular}{|c|c|c|c|c|}
\hline & $\begin{array}{l}\text { Lake density } \\
\text { (ind } \mathrm{L}^{-1} \text { ) }\end{array}$ & $\begin{array}{l}\text { Frequency of } \\
\text { occurrence }\end{array}$ & $\begin{array}{c}\text { Percentage of } \\
\text { prey }\end{array}$ & $\begin{array}{l}\text { Selectivity } \\
\text { index (V) }\end{array}$ \\
\hline \multicolumn{5}{|l|}{ Copepoda } \\
\hline Eudiaptomus padanus padanus & $0.11(0.001)$ & 0.45 & $9.36(21.43)$ & 0.06 \\
\hline Mesocyclops leuckarti & - & - & - & \\
\hline \multicolumn{5}{|l|}{ Cladocera } \\
\hline $\begin{array}{l}\text { Daphnia complex hyalina } \times \text { galeata } \times \\
\text { cucullata }\end{array}$ & $5.69(0.040)$ & 0.95 & $89.87(21.38)$ & $0.44 *$ \\
\hline Eubosmina longirostris & $0.0054(0.010)$ & 0.05 & $0.76(3.55)$ & 0.02 \\
\hline Diaphanosoma brachyurum & - & - & - & \\
\hline \multicolumn{5}{|l|}{ Rotifera } \\
\hline Asplachna priodonta & $0.00044(0.000089)$ & 0 & 0 & -0.005 \\
\hline Keratella cochlearis & $0.072(-)$ & 0 & 0 & -0.07 \\
\hline Keratella quadrata & $0.072(-)$ & 0 & 0 & -0.07 \\
\hline Polyarthra sp. & $6.31(-)$ & 0 & 0 & $-0.64 *$ \\
\hline Filinia sp. & - & - & - & \\
\hline Trichocerca sp. & $1.40(-)$ & 0 & 0 & $-0.30 *$ \\
\hline Pompholix sp. & $0.25(-)$ & 0 & 0 & -0.12 \\
\hline Brachionus sp. & - & - & - & \\
\hline \multicolumn{5}{|l|}{ Diptera } \\
\hline Chaoborus flavicans & 0.04 & 0 & 0 & $-0.26 *$ \\
\hline
\end{tabular}

tions in the days before the sampling, together with the lack of relevant hydrodynamics in the lake, other active factors may have played a role in determining the uneven distribution of specimens, such as feeding activity (Boothroyd et al. 2002). Where present, medusae were preferentially located between a depth of $50 \mathrm{~cm}$ and $2 \mathrm{~m}$. However, we cannot exclude the presence of specimens at depths greater than the transparency of water (about $4 \mathrm{~m}$ ) because massive vertical migrations have been recorded, with a higher density at the surface only during the night (Spadinger \& Maier 1999). The average umbrella/bell diameter was $13.2 \mathrm{~mm}$ (11.016.0), a value smaller than that reported in the literature, which includes a diameter up to $25 \mathrm{~mm}$ (Spadinger \& Maier 1999; Jankowski 2001; Pérez-Bote et al. 2006). The observation of gonads did not reveal the presence of either eggs or sperm, indicating that all of the specimens were still immature, a finding that is consistent with their small dimension. Sexual maturity is reached after 5-6 weeks from their metamorphosis (Acker \& Muscat 1976), and the bloom was probably in its initial phases at the time of sampling.
All medusae had prey in their stomachs. The most frequent zooplanktonic species in the lake during the present study were species of the cladoceran Daphnia galeata $\times$ hyalina $\times$ cucullata complex and the rotifer Polyarthra sp. (Tab. 2). Copepods were represented only by the calanoid E. padanus padanus. The most frequent prey in the stomachs of $C$. sowerbii were young daphniids of the Daphnia complex, mostly 0.9-1.6 mm in length, while diaptomid copepodites were also found in the stomachs, although their numbers were comparatively low. Negative to positive selection was obtained for members of the Daphnia complex and the rotifers Polyarthra sp. and Trichocerca sp., in addition to the dipteran Chaoborus flavicans (Tab. 2). In contrast with reports in the literature (Spadinger \& Maier 1999; Pérez-Bote et al. 2006), diaptomids were not selected, but the low density of these taxa in the community can explain this inconsistency. While negative selection for small rotifers has been demonstrated (Dodson \& Cooper 1983), neutral selection for a big rotifer such as Asplanchna sp. was unusual, being one of the preferred prey of $C$. sowerbii according to the same literature. 
Again, the low density of these taxa in Lake Malpaga may explain this discordance. Finally, apparent negative selectivity was observed for Chaoborus flavicans, which was never present in the stomachs, despite the non-negligible density detected in the lake. However, the size of the sampled specimens (up to $10 \mathrm{~mm}$ ), which were all at the third or fourth developmental stage, largely exceeded the upper dimensional limit estimated for preferential C. sowerbii prey (Spadinger \& Maier 1999).

Basically, the low diversity and density of potential prey in this lake strongly drive food preference towards young daphniids of the Daphnia complex, which fall within the 0.2-2.0 $\mathrm{mm}$ size range [even within the stricter 0.4-1.4 mm estimate of Spadinger \& Maier (1999)] generally accepted for C. sowerbii prey (Dodson \& Cooper 1983). Similarly, the low plankton density probably limits the density of $C$. sowerbii.

In conclusion, this new record of $C$. sowerbii in Italian waters suggests the distribution range of this species may be largely underestimated and unknown. Moreover, a potential shift of the zooplankton community due to this allochtonous species, particularly in oligo-mesotrophic basins like Lake Malpaga, cannot be excluded, and further study should be undertaken in this regard.

\section{ACKNOWLEDGMENTS}

We thank Alba Varallo for her invaluable help with chemical analysis of water samples. We also thank Adam Petrusek for his help concerning sex determination of collected specimens.

\section{REFERENCES}

Acker, T.S. 1976. Craspedacusta sowerbyi: an analysis of an introduced species. In: Mackie, G.O. (Ed.), Coelenterate Ecology and Behavior. Plenum Press, New York: 219-226.

Acker, T.S. \& A.M. Muscat. 1976. Ecology of Craspedacusta sowerbii Lankester, a freshwater hydrozoan. Am. Midl. Nat., 95: 323-336.

Badino, G. \& E. Lodi. 1972. The medusa Craspedacusta sowerbyi Lankester (Limnomedusae) from Lake Sirio (Ivrea, Italy). Boll. Pesca Piscic. Idrobiol., 27: 293-296.

Boothroyd, I.K.G., M.K Etheredge \& J.D. Green. 2002. Spatial distribution, size structure, and prey of Craspedacusta sowerbyi Lankester in a shallow New Zealand lake. Hydrobiologia, 468: 23-32.

Bouillon, J. \& F. Boero. 2000. The hydrozoa: a new classification in the light of old knowledge. Thalassia Salentina, 24: 3-45.

Cotta Ramusino, M. 1972. Présence de la Craspedacusta sowerbyi Lank. dans les eaux italiennes. Bull. Fr. Piscic., 245: $147-150$

Devries, D.R. 1992. The freshwater jellyfish Craspedacusta sowerbyi: a summary of its life history, ecology and distribution. J. Freshwat. Ecol., 7: 7-16.

Dodson, S.I. \& S.D. Cooper. 1983. Trophic relationships of the freshwater jellyfish Craspedacusta sowerbyi Lankester 1880. Limnol. Oceanogr., 28: 345-351.

Dumont, H.J. 1994. The distribution and ecology of the fresh and brackish-water medusae of the world. Hydrobiologia, 272: 1-12.

Received: September 2009

Accepted: October 2009
Fritz, G.B., R.O. Schill, M. Pfannkuchen \& F. Brümmer. 2007. The freshwater jellyfish Craspedacusta sowerbii Lankester, 1880 (Limnomedusa: Olindiidae) in Germany, with a brief note on its nomenclature. J. Limnol., 66: 54-59.

Fritz, G.B., M. Pfannkuchen, A. Reuner, R.O. Schill \& F. Brümmer. 2009. Craspedacusta sowerbii, Lankester 1880: population dispersal analysis using COI and ITS sequences. J. Limnol., 68: 46-52.

Gliwicz, Z.M., P. Dawidowicz \& P. Maszczyk. 2006. Low density anti-predation refuge in Daphnia and Chaoborus? Arch. Hydrobiol., 167: 101-114.

Jankowski, T. 2001. The freshwater medusae of the world: A taxonomic and systematic literature study with some remarks on other inland water jellyfish. Hydrobiologia, 462: 91-113.

Jankowski, T. 2004. Predation of freshwater jellyfish on Bosmina: the consequences for population dynamics, body size, and morphology. Hydrobiologia, 530: 121-128.

Jankowski, T., T. Strauss \& H.T. Ratte. 2005. Trophic interactions of the freshwater jellyfish Craspedacusta sowerbii. J. Plankton Res., 27: 811-823.

Kramp, P.L. 1961. Synopsis of the Medusae of the world. Order Limnomedusae. J. Mar. Biol., 40: 213-236.

Leoni, B., G. Morabito, M. Rogora, D. Pollastro, R. Mosello, S. Arisci, E. Forasacco \& L. Garibaldi. 2007. Response of planktonic communities to calcium hydroxide addition in an hardwater eutrophic lake: results from a mesocosm experiment. Limnology, 8: 121-130.

Marchetti, R., M. Cotta Ramusino \& G.C. Melone. 1968. Indagine sul torrente Seveso. Inventario del carico biologico (parte II). Acqua Industriale, 57: 24.

McClary, A. 1959. Growth and differentiation in Craspedacusta sowerbyi. Ph.D. Thesis, University of Michigan.

McQueen, D.J., C.W. Ramcharan, E. Demers, N.D. Yan, L.M. Conforti \& A. Pérez-Fuentaja. 1999. Chaoborus behavioural responses to changes in fish density. Arch. Hydrobiol., 145: 165-179.

Pearre, S. 1982. Estimating prey preferences by predators: uses of various indices, and a proposal of another based on $\chi^{2}$. Can. J. Fish. aquat. Sci., 39: 914-923.

Pérez-Bote, J.L., A. Muñoz, R. Morán, R. Roso \& A.J. Romero. 2006. First record of Craspedacusta sowerbyi Lankester, 1880 (Cnidaria: Limnomedusae: Olindiidae) in the Proserpina Reservoir (Extremadura, Spain) with notes on their feeding habits. Belg. J. Zool., 136: 163-166.

Ramazzotti, G. 1962. Ritrovamento della medusa dulciacquicola Craspedacusta sowerbyi nella regione del Lago Maggiore. Mem. Ist. ital. Idrobiol., 15: 175-181.

Rayner, N.A. 1988. First record of Craspedacusta sowerbyi Lankester (Cnidaria: Limnomedusae) from Africa. Hydrobiologia, 162: 73-77.

Reisinger, E. 1957. Zur Entwicklungsgeschichte und Entwicklungsmechanik von Craspedacusta (Hydrozoa, Limnotrachylina). Z. Morphol. Ökol. Tiere, 45: 656-698.

Smith, A.S. \& J.E. Alexander. 2008. Potential effects of the freshwater jellyfish Craspedacusta sowerbii on zooplankton community abundance. J. Plankton Res., 30: 1323-1327.

Spadinger, R. \& G. Maier. 1999. Prey selection and diel feeding of the freshwater jellyfish, Craspedacusta sowerbyi. Freshwat. Biol., 41: 567-573.

Stefanelli, A. 1948. Una medusa d'acqua dolce del genere Craspedacusta sviluppatasi in una vasca dell'Istituto. Ital. J. Zool.,15: 41-47.

Zhang, L.Q., G.T. Wang, W.J. Yao, W.X. Li \& Q. Gao. 2009. Molecular systematics of medusae in the genus Craspedacusta (Cnidaria: Hydrozoa: Limnomedusae) in China with the reference to the identity of species. J. Plankton Res., 31: 563-570. 